Eur. J. Clin. Chem. Clin. Biochem.

Vol. 31, 1993, pp. $773-776$

(C) 1993 Walter de Gruyter \& Co.

Berlin · New York

\title{
Effect of Different Columns and Internal Standards on the Quality Assurance of the Gas Chromatographic Determination of Blood Ethanol
}

\author{
By M. Varga, G. Somogyi, J. Posta and L. Buris \\ Department of Forensic Medicine, University Medical School of Debrecen, Hungary
}

(Received June 7/July 12, 1993)

\begin{abstract}
Summary: Quality assurance is an essential requirement of clinical and forensic laboratories, especially in the determination of ethanol. Opinions differ as to whether normal gas chromatographic methods should be used with modified procedures, or whether different chromatographic strategies should be adopted, the choice being based entirely on practical considerations. We have evaluated the influence on the blood ethanol determination of the frequently used glass and steel columns, as well as the use of isopropanol and tertbutanol as internal standards. All the different combinations of column type and standard provided accurate and reliable results with no significant deviation. Standardization of the analytical procedure is therefore unnecessary, but international ethanol standards should be analysed sequentially to test the method and the staff performing the analyses in the different laboratories.
\end{abstract}

\section{Introduction}

The clinical and forensic laboratory is responsible for providing results which are as precise and accurate as possible $(1-2)$. It is generally accepted that two methods, an oxido-reductimetric and a gas chromatographic method for the determination of blood ethanol concentration, are statuary in forensic practice $(3-4)$. Gas chromatography is generally recommended for identification and quantitation of volatile polar organic compounds such as ethanol in body fluids $(5-6)$. Different chromatographic strategies for blood ethanol determination can be adopted for clinical and forensic purposes (7). Sampling techniques include headspace analysis $(8-10)$, liquid-liquid extractions and direct injection of body fluids. If both blood and urine samples are to be analysed, the direct injection of diluted plasma samples, which minimizes sample handling and allows rapid feedback of data, is preferred $(11=12)$. Syringe blockage can be minimized by using removable needles or by washing the syringe. The injection port must be regularly cleaned of residues from biological samples.
Quality assurance has become an essential element of clinical and forensic science. All aspects of performance should be monitored to ensure that the highest possible standards are maintained (13). Quality assurance is a potentially worthless exercise if precautions have not been taken to avoid contamination prior to the submission of items to the laboratories. Many trials have been focussed on the determination of ethanol in blood and urine in forensic laboratories, and it is assumed that test materials should be examined in exactly the same way (14). However, alcohols can be efficiently separated by different GC methods and the choice is based only on practical considerations (7).

The purpose of the present report is not to demonstrate differences, but to show that different operating conditions are all satisfactory for the assay of blood ethanol. This was done by evaluating the effect of different combinations of two types of frequently used column materials and two internal standards on the gas chromatographic ethanol determination. 


\section{Materials and Methods}

The instrument used was a Hewlett Packard HP 5710 A equipped with a flame ionization detector and a HP Chem System for data processing. The column was $1.8 \mathrm{~m} \times 3 \mathrm{~mm}$ (i. d.) stainless steel or glass tube (Supelco Inc. Bellefonte, PA) packed with Porapak-S (80/100 mesh) which gives very sharp peaks, quick elution (within 2.5 minutes) and resolves acetone from ethanol. The flame ionization detector temperature was at $250^{\circ} \mathrm{C}$. The temperatures of injection port and the separator oven temperature were $250^{\circ} \mathrm{C}$ and $180^{\circ} \mathrm{C}$, respectively. The carrier gas was $\mathrm{N}_{2}$ at a flow rate of $40 \mathrm{ml} / \mathrm{min}$, with an inlet pressure of $1.8 \mathrm{~kg} / \mathrm{cm}^{2}$. Solutions of $2 \mathrm{~g} \cdot \mathrm{l}^{-1}$ isopropanol and tert-butanol (two commonly used internal standards) were used (7). All chemicals were of HPLC quality, purchased from Merck. Blood samples from 500 forensic cases were analysed for ethanol content under identical experimental conditions, except for the type of column material and the internal standard. Duplicate determinations on each blood specimen were made with all combinations of the two columns and the two internal standards.

The blood samples were collected from suspected drinking drivers and contained potassium oxalate as anticoagulant. According to physicians' reports none of the drivers were starved, diabetic or seyerely ill. No preservatives were added to the samples. Blood samples were diluted 1:1 with the aqueous solution containing the internal standards and were analysed as $1 \mu \mathrm{l}$ direct injections. The syringe was thoroughly washed with water immediately after each injection. Although chromatographic properties of the columns were unaffected by this number of repeated injections the injection port was regularly cleaned.

The following conditions were compared for the determination of the blood alcohol concentration: different columns but same internal standard; same column but different internal standards; different columns and different internal standards. The mean and relative differences were calculated for each pair of deter- minations. Both between-assay and within-assay reproducibilities were evaluated from the analyses of 10 replicate samples for two different concentrations of ethanol prepared from absolute alcohol (E. Merck). The ethanol concentrations were 50 and $500 \mathrm{mg} \cdot 1^{-1}$. In order to efficiently determine the betweenassay and within-assay reproducibility we used the variation coefficient expressed as the ratio of the mean square deviation to the arithmetic mean, expressed as a percentage.

The statistical examinations and data analyses were carried out by standard statistical method by using C-Stat software (Cherwell Scientific Publishing, Oxford), with a microcomputer for descriptive statistics and significance testing.

\section{Results and Discussion}

Both between-assay and within-assay reproducibilities summarized in table 1 showed that the methods have similar precisions under all the applied conditions. The variation coefficients of replicate $(n=10)$ analyses of two ethanol concentrations ranged from $0.83 \%$ to $1.71 \%$. The detection limit, defined as the lowest concentration resulting in a signal-to-noise ratio of 4 , was $2 \mathrm{mg} \cdot 1^{-1}$ ethanol. Values below this limit, due to endogeneous alcohol, have no forensic significance. The concentrations of ethanol in forensic blood samples collected from suspected drinking drivers showed a range of $0-4.97 \mathrm{mg} \cdot 1^{-1}$. Table 2 shows the differences between the blood ethanol concentrations determined with isopropanol or tert-butanol as internal standards making use of different types of

Tab. 1. Between-assay and within-assay reproducibilities expressed as means of variation coefficients of replicate $(n=10)$ analyses of two ethanol concentrations $\left(50.0 ; 500.0 \mathrm{mg} \cdot 1^{-1}\right)$, using different GC conditions

\begin{tabular}{|c|c|c|c|c|}
\hline \multirow{3}{*}{$\begin{array}{l}\text { Ethanol concentration } \\
{\left[\mathrm{mg} \cdot 1^{-1}\right]}\end{array}$} & \multicolumn{4}{|c|}{ Variation coefficient [\%] } \\
\hline & \multicolumn{2}{|l|}{ Glass column } & \multicolumn{2}{|l|}{ Steel column } \\
\hline & Isopropanol & tert-Butanol & Isopropanol & tert-Butanol \\
\hline \multicolumn{5}{|l|}{ Within-assay imprecision } \\
\hline $\begin{array}{r}50.0 \\
500.0\end{array}$ & $\begin{array}{l}1.66 \\
1.21\end{array}$ & $\begin{array}{l}1.41 \\
0.99\end{array}$ & $\begin{array}{l}1.27 \\
0.83\end{array}$ & $\begin{array}{l}1.37 \\
1.01\end{array}$ \\
\hline \multicolumn{5}{|c|}{ Between-assay imprecision } \\
\hline $\begin{array}{r}50.0 \\
500.0\end{array}$ & $\begin{array}{l}1.67 \\
1.39\end{array}$ & $\begin{array}{l}1.71 \\
0.93\end{array}$ & $\begin{array}{l}1.46 \\
1.08\end{array}$ & $\begin{array}{l}1.59 \\
1.17\end{array}$ \\
\hline
\end{tabular}

Tab. 2. Effect of different GC columns on blood ethanol determination using the same internal standards

\begin{tabular}{|c|c|c|c|c|c|c|c|}
\hline $\begin{array}{l}\text { Internal } \\
\text { standard }\end{array}$ & Column & $\begin{array}{l}\text { Mean blood } \\
\text { alcohol } \\
\text { concen- } \\
\text { trations } \\
{\left[\mathrm{mg} \cdot \mathrm{1}^{-1}\right]}\end{array}$ & $\begin{array}{l}\text { Mean } \\
\text { difference } \\
\text { Steel-Glass } \\
{[\%]}\end{array}$ & $\begin{array}{l}\begin{array}{l}\text { Mean } \\
\text { difference SD }\end{array} \\
{\left[\mathrm{mg} \cdot 1^{-}\right]}\end{array}$ & $\begin{array}{l}\text { Relative difference } \\
\frac{\text { Steel-Glass }}{\text { Steel }} \cdot 100\end{array}$ & $\begin{array}{l}\text { Corre- } \\
\text { lation }\end{array}$ & $p$ \\
\hline $\begin{array}{l}\text { Isopropanol } \\
\text { Isopropanol } \\
\text { tert-Butanol } \\
\text { tert-Butanol }\end{array}$ & $\begin{array}{l}\text { Steel } \\
\text { Glass } \\
\text { Steel } \\
\text { Glass }\end{array}$ & $\begin{array}{l}1.1610 \\
1.1679 \\
1.1442 \\
1.1376\end{array}$ & $\begin{array}{l}-0.0069 \\
+0.0066\end{array}$ & 0.0154 & $\begin{array}{l}-0.59 \\
+0.57\end{array}$ & 0.997 & NS \\
\hline
\end{tabular}


GC columns. The differences between the two determinations using glass or steel columns with both internal standards are not significant, the relative mean differences being 0.59 and $0.57 \%$, respectively. Table 3 shows the influence of the internal standards on the blood ethanol determination, using the same type of GC column. Different internal standards with a steel column resulted in a mean relative difference of $1.43 \%$. The highest difference between means $(2.59 \%)$, although not significant, was observed with glass columns and different internal standards. When both the column and the internal standard were different, the differences were 2.02 and $2.03 \%$ as seen in table 4. The in-run reproducibility is reported to be $1.4-3.9 \%$ in different laboratories, and $2.9-5.2 \%$ for different blood ethanol concentrations (6). The error generally caused by the instrumentation is about $2 \%$. None of the differences we measured was significant and they did not exceed the errors mentioned. Thus the use of different types of GC columns or different internal standards is acceptable.

As shown in figure 1, the applied standard GC procedure at $250 / 180^{\circ} \mathrm{C}$ efficiently separated ethanol and possible bioproducts such as acetone, acetaldehyde, acetic acid.

Because of the forensic implications, clinical laboratories are responsible for providing results which are as precise and accurate as possible, but it does not seem to be necessary to make exclusive recommendations regarding detailed procedures and instrumentation. Alcohols can be efficiently separated with dif-

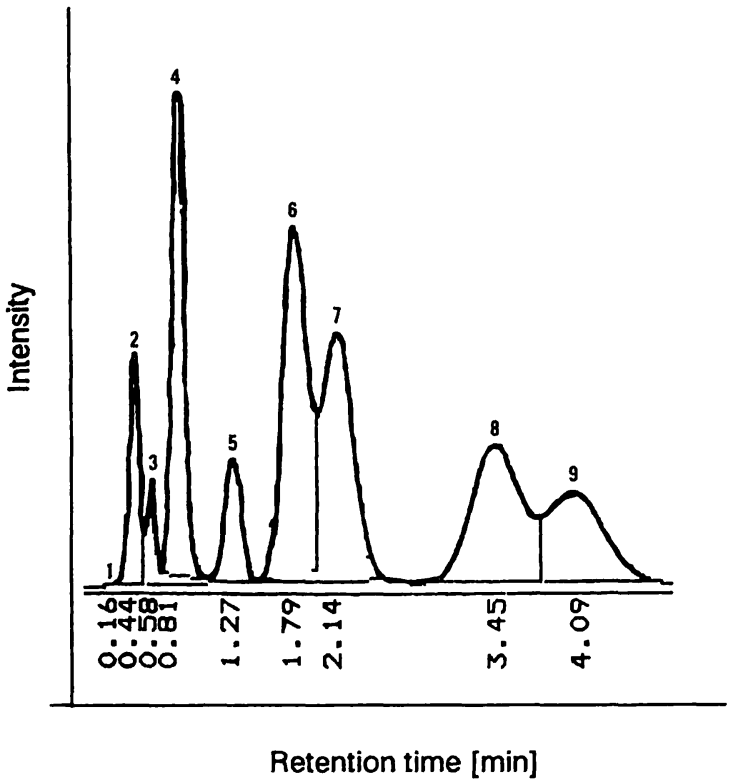

Fig. 1. Separation diagram of the gas chromatographic method (1, water; 2 , methanol; 3 , acetaldehyde; 4 , ethanol; 5 , acetone; 6 , acetic acid; 7 , tert-butanol; $8, n$-butanol; 9 , isobutanol)

ferent GC strategies and the choice is based on practical considerations (consumed time and cost of the analysis, multipurpose application of the instrumentation etc.). If there is no external quality assessment scheme for blood or urine ethanol assays, a rigorous internal quality control procedure should operate in the laboratory undertaking ethanol assays. It is essential to have confidence in both the method used and the staff performing the analysis. Appropiate control specimens, which can be internationally issued and circulated, should be analysed sequentially.

Tab. 3. Effect of different internal standards on blood ethanol determination using the same GC columns

\begin{tabular}{|c|c|c|c|c|c|c|c|}
\hline $\begin{array}{l}\text { Internal } \\
\text { standard }\end{array}$ & Column & $\begin{array}{l}\text { Mean } \\
\text { blood } \\
\text { alcohol } \\
\text { concen- } \\
\text { tration } \\
{\left[\mathrm{mg} \cdot 1^{-1}\right]}\end{array}$ & $\begin{array}{l}\text { Mean } \\
\text { difference } \\
\text { Iso- } \\
\text { propanol- } \\
\text { tert-Butanol } \\
{[\%]}\end{array}$ & $\begin{array}{l}\text { Mean } \\
\text { difference } \\
\text { SD } \\
{\left[\mathrm{mg} \cdot 1^{-1}\right]}\end{array}$ & $\begin{array}{l}\text { Relative difference } \\
\frac{\text { Isopropanol - tert-Butanol }}{\text { Isopropanol }} \cdot 100\end{array}$ & $\begin{array}{l}\text { Corre- } \\
\text { lation }\end{array}$ & $\mathrm{p}$ \\
\hline $\begin{array}{l}\text { Isopropanol } \\
\text { tert-Butanol }\end{array}$ & $\begin{array}{l}\text { Steel } \\
\text { Steel }\end{array}$ & $\begin{array}{l}1.1610 \\
1.442\end{array}$ & +0.0167 & 0.0827 & +1.43 & 0.998 & NS \\
\hline $\begin{array}{l}\text { Isopropanol } \\
\text { tert-Butanol }\end{array}$ & $\begin{array}{l}\text { Glass } \\
\text { Glass }\end{array}$ & $\begin{array}{l}1.1679 \\
1.1376\end{array}$ & $\cdot+0.0303$ & 0.1227 & +2.59 & 0.984 & NS \\
\hline
\end{tabular}

Tab. 4. Comparison of the blood ethanol determinations using different internal standards and GC columns

\begin{tabular}{|c|c|c|c|c|c|c|c|}
\hline $\begin{array}{l}\text { Internal } \\
\text { standard }\end{array}$ & Column & $\begin{array}{l}\text { Mean blood } \\
\text { alcohol } \\
\text { concentration } \\
{\left[\mathrm{mg} \cdot 1^{-1}\right]}\end{array}$ & $\begin{array}{l}\text { Mean } \\
\text { difference } \\
\text { I-II } \\
{[\%]}\end{array}$ & $\begin{array}{l}\begin{array}{l}\text { Mean } \\
\text { difference }\end{array} \\
{\left[\mathrm{mg} \cdot 1^{-1}\right]}\end{array}$ & $\begin{array}{l}\text { Relative difference } \\
\frac{\mathrm{I}-\mathrm{II}}{\mathrm{I}} \cdot 100\end{array}$ & $\begin{array}{l}\text { Corre- } \\
\text { lation }\end{array}$ & $\mathrm{p}$ \\
\hline $\begin{array}{l}\text { I Isopropanol' } \\
\text { II tert-Butanol }\end{array}$ & $\begin{array}{l}\text { Steel } \\
\text { Glass }\end{array}$ & $\begin{array}{l}1.1610 \\
1.1376\end{array}$ & +0.0234 & 0.1019 & +2.02 & 0.986 & NS \\
\hline $\begin{array}{l}\text { I Isopropanol } \\
\text { II tert-Butanol }\end{array}$ & $\begin{array}{l}\text { Glass } \\
\text { Steel }\end{array}$ & $\begin{array}{l}1.1679 \\
1.1442\end{array}$ & +0.0237 & 0.1029 & +2.03 & 0.985 & NS \\
\hline
\end{tabular}




\section{References}

1. Weiler, G., Schütz, H. \& Erdmann, F. (1991) Critical questions concerning the role of standard deviation as precision parameter for blood alcohol determination. Blutalkohol $28,146-149$.

2. Wright, J. W. (1991) Alcohol and the laboratory in the United Kingdom. Ann. Clin. Biochem. 28, 212-217.

3. Garriot, J. C. (ed.) Medicolegal Aspects of Alcohol Determination in Biological Specimens. PSG, Littleton.

4. Machata, G. (1983) Concerning the question of "Two different methods" for determination of blood alcohol concentration. Blutalkohol 20, 236-240.

5. Minty, P. S. B. (1987) The role of gas chromatography in forensic medicine and toxicology. Int. Laboratory 7-8, $28-36$.

6. Warnet, J. M., Boudène, C., Cluet, J. L., François, E., Goulle, J.-P., Le Henaff, Y., Leblanc, A., Lenegre, F., Leymarie, M., Mousson,. B., Pailler, F.-M., Papoz, L., Ricordel, I., Rudler, M., Thevenin, M. \& Tourneau, J. (1990) Evaluation of gas-chromatography method to determine blood-ethanol. Ann. Biol. Clin. 48, 587-595.

7. Tagliaro, F. \& Lubli, G. (1992) Chromatographic methods for blood alcohol determination. J. Chromatography 580 , $161-190$.
8. Bilzer, N. \& Grüner, O. (1983) Critical assessment regarding determination of aliphatic alcohols in blood with the aid of head-space-analysis. Blutalkohol 20, 411-421.

9. Clendenning, B. L. \& harvey, R. A. (1969) Using head space gas for determination of blood alcohol by gas chromatography. J. Forens. Sci. 14, 136-144.

10. Meyer, T. (1978) Determination of ethanol in biological samples by head-space gas chromatography using glass capillary column. Acta Pharmacol. Toxicol. 43, 164-168.

11. Manno, B. R. \& Manno, J. E. (1978) A simple approach to gas chromatographic microanalysis of alcohols in blood and urine by a direct injection technique. J. Anal. Toxicol. $2,257-261$

12. Jennings, W. \& Mehran, M. F. (1986) Sample injection in gas chromatography. J. Chromatogr. Sci. 24, 34-40.

13. Stone, H. M., Muirhead, J. M., Norris, R. J. \& Singers, W. A. (1980) The accuracy, precision and comparison of methods of blood alcohol analysis by gas chromatography. CD 2305, pp. 1-40. Chemistry Division Report, Dept. of Scientific \& Industrial Research, New Zealand.

14. Pereira, M. (1988) Quality assurance in forensic science. Forensic Sci. Int. 28, 1-6.

Dr. Milhály Varga Department of Forensic Medicine University Medical School of Debrecen P. O. Box 25 H-4012 Debrecen Hungary 